Original

\title{
In vitro evaluation of the cytotoxicity of ProRoot MTA and MTA Angelus
}

\author{
Elisabeth A. Koulaouzidou ${ }^{1)}$, Nikolaos Economides ${ }^{2)}$, Panagiotis Beltes ${ }^{2)}$, \\ George Geromichalos ${ }^{3)}$ and Konstantinos Papazisis ${ }^{3)}$ \\ ${ }^{1)}$ Department of Operative Dentistry, Faculty of Dentistry, Aristotle University of Thessaloniki, \\ Thessaloniki, Greece \\ ${ }^{2}$ Department of Endodontology, Faculty of Dentistry, Aristotle University of Thessaloniki, \\ Thessaloniki, Greece \\ ${ }^{3)}$ Theagenion Cancer Institute, Thessaloniki, Greece
}

(Received 28 April and accepted 29 September 2008)

\begin{abstract}
The purpose of the present in vitro study was to compare the cytotoxic effect of two commercially available brands of mineral trioxide cement (ProRoot MTA and MTA Angelus), modified zinc oxide-eugenol cement (SuperEBA) and resin-modified glass ionomer cement (Vitrebond) using rat pulp cells (RPC-C2A) and human lung fibroblasts (MRC-5). The cells were cultured in typical culture conditions and exposed to the tested materials by adaptation of insert wells. The cytotoxic effect was recorded at two observation periods (24 and $72 \mathrm{~h}$ ) by using a colorimetric assay of tetrazolium reduction (XTT method) in reference to controls. Overall, the degree of cytotoxic effect in ascending order was ProRoot MTA - MTA Angelus < SuperEBA < Vitrebond. Both MTA materials tested exerted mild suppression of cellular mitochondrial activity and may be characterized as biologically inert materials. (J. Oral Sci. 50, 397-402, 2008)
\end{abstract}

Keywords: mineral trioxide aggregate; cytotoxicity; XTT method; pulp cells.

Correspondence to Dr. Elisabeth A. Koulaouzidou, 1 Xenofontos Street, GR 55132 Kalamaria, Thessaloniki, Greece

Tel: +30-2310-482233

Fax: +30-2310-999616

E-mail: koulaouz@dent.auth.gr

\section{Introduction}

Mineral trioxide aggregate (MTA) has been proposed for use as root-end filling material $(1,2)$, root or furcal perforation repair material (3) and apexification and obturation of the root canal system (4,5). Additionally, MTA is an effective pulp capping material able to stimulate reparative dentine formation by the stereotypic defensive mechanism of early pulpal wound healing $(6,7)$. The material is based on Portland cement except for the addition of bismuth oxide to improve radiopacity. In the dental market, two commercial brands are available - the ProRoot MTA and the MTA Angelus, which was recently introduced. Although several studies reported the biological effects of ProRoot MTA, only a small amount of scientific information has been published on the comparative evaluation of the biocompatibility of ProRoot MTA and MTA Angelus (8-10). Specifically, no data exist on MTA Angelus and its biocompatibility on cells of dental origin, such as pulp cells.

During routine clinical procedures, it is possible to expose the pulp tissue and proceed to pulp capping to preserve pulp vitality and promote healing and function. Several factors influence the pulp capping procedure, such as age, stage of root formation, size of exposure, microbial contamination etc.

Over the years, a number of materials have been proposed for pulp capping including zinc oxide-eugenol cements, calcium hydroxide cements and conventional or resin modified glass ionomer cements (RMGICs), which are 
characterized by improved physical and mechanical properties compared to conventional glass ionomer cements (11). Recently developed materials, such as MTA, have also been proposed as effective pulp capping materials based on their ability to stimulate pulp tissue repair and promote dentin bridge formation $(6,12,13)$.

Studies with cell cultures may offer a significant tool to improve our knowledge of possible toxic effects of materials and for predicting these effects on humans. Furthermore, in vitro tests are simple to perform, repeatable, cost-effective, relevant and suitable as an alternative to in vivo experiments. The in vitro assays usually estimate cell numbers after exposure to the tested materials and reference to control cells produces a survival fraction, i.e. the percentage of viable cells at the end of the in vitro experiment.

The purpose of the present study was to evaluate the cytotoxic effect of two commercial brands of MTA (ProRoot MTA and MTA Angelus), a zinc oxide-eugenol cement (SuperEBA) and a resin modified glass ionomer cement (Vitrebond) using a cell viability assay for mitochondrial dehydrogenase activity in rat pulp cells and human lung fibroblasts.

\section{Materials and Methods}

\section{Cell lines and culture conditions}

Human fibroblasts (MRC-5; obtained from Theagenion Cancer Tissue Bank) and rat pulp cells (RPC-C2A; gift from Professor S. Kasugai, Department of Pharmacology, Faculty of Dentistry, Tokyo Medical and Dental University, Japan) were grown as monolayer cultures in T-75 flasks (Costar/Corning), subcultured twice a week at $37^{\circ} \mathrm{C}$ in an atmosphere containing $5 \% \mathrm{CO}_{2}$ in air and $100 \%$ relative humidity. The culture medium was Dulbecco's modified Eagle medium (DMEM, Gibco, Glasgow, UK), supplemented with $10 \%$ fetal bovine serum (FBS, Gibco, Glasgow, UK), $100 \mu \mathrm{g} / \mathrm{ml}$ streptomycin and $100 \mathrm{IU} / \mathrm{ml}$ penicillin.

Adherent cells at a logarithmic growth phase were detached by the addition of $2-3 \mathrm{ml}$ of a $0.05 \%$ trypsin (Gibco, 1:250) and 0.02\% EDTA mixture and incubated for $2-5 \mathrm{~min}$ at $37^{\circ} \mathrm{C}$. As determined by hemocytometry, cells were plated on 12-well plates (Costar-Corning, Cambridge) at a density of 30,000 cells per well in complete medium and were placed in the incubator for $24 \mathrm{~h}$ to obtain exponential cell growth.

\section{Preparation of test materials}

The tested materials were: white ProRoot MTA (Dentsply, York, PA, USA); white MTA Angelus (Angelus, Londrina, Brazil); SuperEBA (Bosworth Co., Skokie, IL,
USA); and Vitrebond (3M/ESPE, St. Paul, MN, USA). All materials were prepared according to the manufacturer's instructions and placed at the bottom of transwell insert wells, with a membrane pore diameter of $0.4 \mu \mathrm{m}$ that fitted in the 12-well microplates. After setting, the insert wells were UV-irradiated $\left(180 \mathrm{~J} / \mathrm{cm}^{2}\right)$, placed into the culture wells and incubated for 24 or $72 \mathrm{~h}$. Six wells per material were prepared. In controls, cells were cultured in 12-well plates with transwell inserts but without any material specimen. After completion of the exposure time, the insert wells were removed and cell numbers were estimated by the 2,3-bis [2-methoxy-4-nitro-5-sulphophenyl]-5[(phenylamino) carbonyl]-2H-tetrazolium hydroxide (XTT) assay.

\section{XTT assay}

The XTT assay was performed as previously described $(14,15)$. Briefly, $500 \mu$ of a mixture $(100: 1)$ of XTT $(1$ $\mathrm{mg} / \mathrm{ml}$ ) (Sigma Chemical Co, St. Louis, MO, USA) with $10 \mathrm{mM}$ menadione (MEN) were added to the wells already containing $2 \mathrm{ml}$ of cells in culture medium and plates were incubated for $4 \mathrm{~h}$ at $37^{\circ} \mathrm{C}$. Absorbance was read in an Elisa plate reader (Anthos 2001) at $450 \mathrm{~nm}$ subtracting the background measurement of $620 \mathrm{~nm}$.

The test optical density (OD) value was defined as the mean absorbance of each individual well, minus the blank value ('blank' is the mean optical density of background control wells). Results were expressed as survival fraction following the equation (ODtest/ODcontrol) $\times 100$. The mean optical density of the control wells (where empty insert wells were applied) was set to represent $100 \%$ viability.

The statistical analysis of the results was performed by Kruskal Wallis test, followed by Mann Whitney test with Bonferroni correction $(P<0.05)$.

\section{Results}

Each experiment was repeated at least twice and the results of typical experiments are presented in Tables 1 and 2. Representative photos of cells after exposure to the tested materials are shown in Fig. 1. Overall the ranking order of the materials tested was Vitrebond $>$ SuperEBA $>$ ProRoot MTA - MTA Angelus.

Vitrebond showed the highest cytotoxic effect and the mitochondrial dehydrogenase activity decreased significantly in RPC-C2A and MRC5 cells after $24 \mathrm{~h}$ or $72 \mathrm{~h}$ of exposure. The cytotoxic effects of Vitrebond and SuperEBA were statistically different $(P<0.05)$ in both cells lines and exposure periods.

Similar results were obtained after exposure to ProRoot MTA and MTA Angelus. Generally both materials showed 
Table 1 Cytotoxicity on RPC-C2A cells of the tested materials after 24 and $72 \mathrm{~h}$ exposure expressed in percent of control

\begin{tabular}{ccc}
\hline & \multicolumn{2}{c}{ Percent viable RPC-C2A cells } \\
Material & $24 \mathrm{~h}$ & $72 \mathrm{~h}$ \\
\hline white MTA Angelus & $92.49 \pm 5.51^{\mathrm{a}}$ & $88.94 \pm 6.81^{\mathrm{A}}$ \\
white ProRoot MTA & $91.20 \pm 4.62^{\mathrm{a}}$ & $81.84 \pm 6.01^{\wedge}$ \\
Super EBA & $52.37 \pm 3.72^{\mathrm{b}}$ & $43.97 \pm 3.29^{\mathrm{B}}$ \\
Vitrebond & $15.06 \pm 2.88^{\mathrm{C}}$ & $10.43 \pm 0.86^{\mathrm{C}}$ \\
\hline
\end{tabular}

Data are shown as mean \pm SD. Same letters in columns denote not statistically significant differences $(P>0.05)$.

Table 2 Cytotoxicity on MRC- 5 cells of five materials at 24 and $72 \mathrm{~h}$ expressed in percent of control

\begin{tabular}{ccc}
\hline & \multicolumn{2}{c}{ Percent viable MRC5 cells } \\
Material & $24 \mathrm{~h}$ & $72 \mathrm{~h}$ \\
\hline white MTA Angelus & $105.39 \pm 6.06^{\mathrm{a}}$ & $90.26 \pm 3.67^{\mathrm{A}}$ \\
white ProRoot MTA & $96.03 \pm 4.19^{\mathrm{a}}$ & $92.15 \pm 6.74^{\mathrm{A}}$ \\
SuperEBA & $63.25 \pm 3.98^{\mathrm{b}}$ & $39.00 \pm 2.51^{\mathrm{B}}$ \\
Vitrebond & $22.06 \pm 5.12^{\mathrm{C}}$ & $19.43 \pm 6.29^{\mathrm{C}}$ \\
\hline
\end{tabular}

Data are shown as mean \pm SD. Same letters in columns denote not statistically significant differences $(P>0.05)$.

(a)

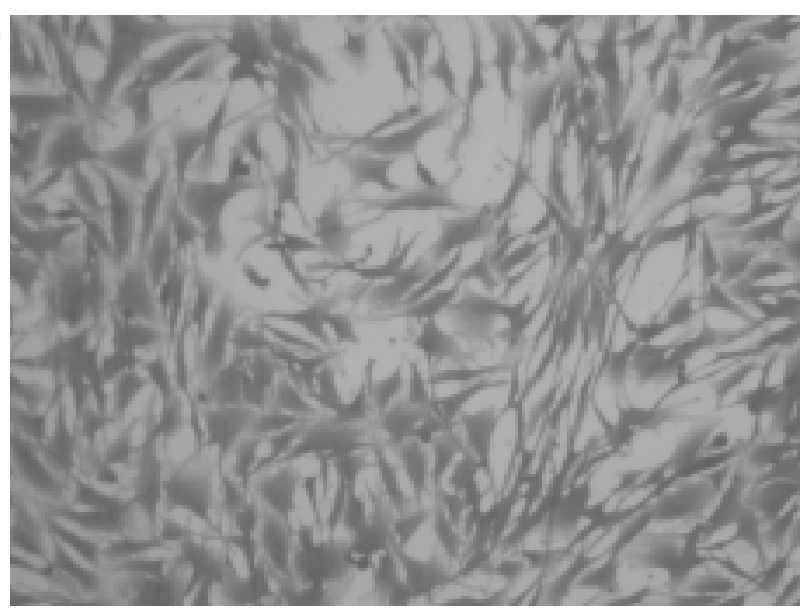

(b)

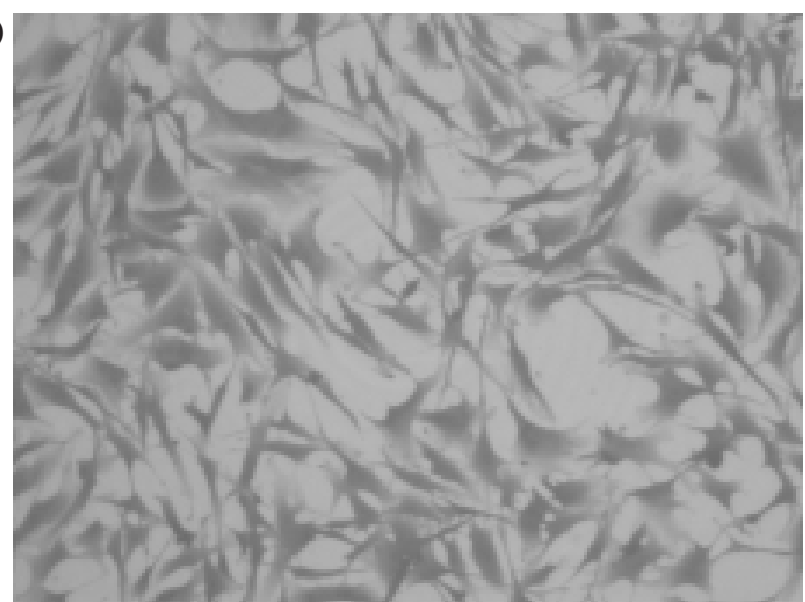

(c)

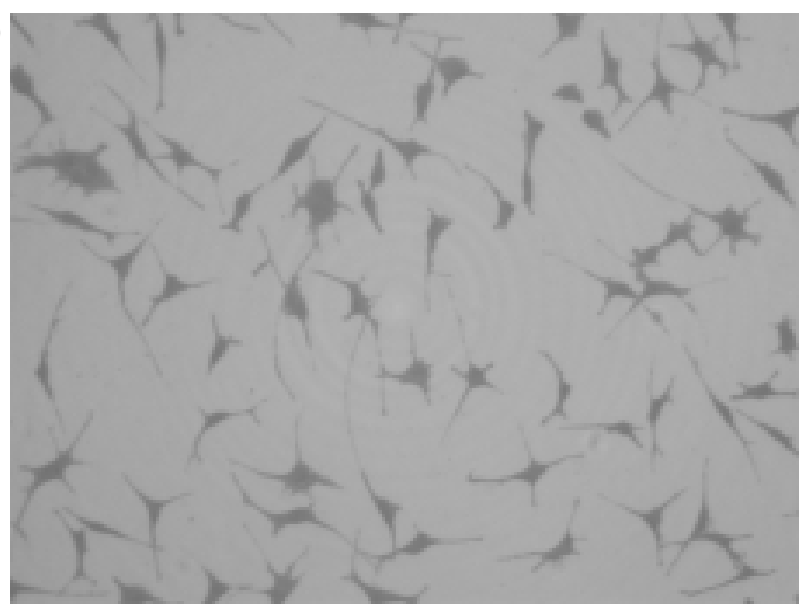

(d)

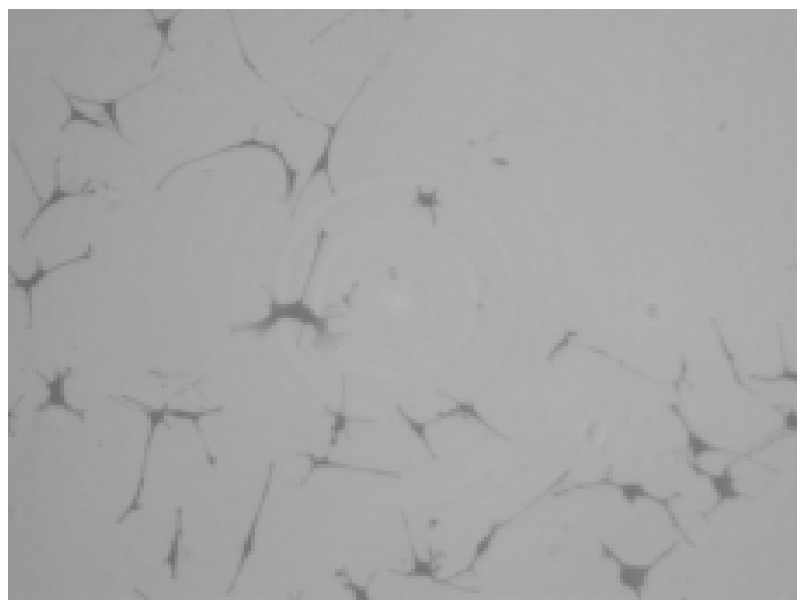

Fig. 1 Representative photos of cells (a) RPC-C2A exposed to white MTA Angelus, (b) RPC-C2A exposed to white ProRoot MTA, (c) MRC5 exposed to SuperEBA and (d) MRC5 exposed to Vitrebond (×200 magnification) 
only slight inhibitory effect on cell viability. The effect of ProRoot MTA and MTA Angelus was statistically significant lower than the effect caused by exposure to Vitrebond and SuperEBA $(P<0.05)$.

\section{Discussion}

The results of the present study showed that MTA Angelus and ProRoot MTA were biocompatible when tested in rat pulp cells and in human lung fibroblasts. For the experimental setting, the cements were placed on the microporous membrane of an insert well that was floating over the culture medium in a multiwell plate. Thus, we evaluated the effects of the set materials on cell survival preventing physical interaction between the investigated material and the target cells (16) and compared the cell survival in the presence of the four tested cements.

RPC-C2A is a clonal cell line that has been established from the dental pulp tissue of the rat incisor by Kasugai et al. (17). The alkaline phosphatase of RPC-C2A cells is biochemically identical with that of the dental pulp and characterized by alkaline phosphatase (ALP) activity as a marker enzyme for cloning (17). These cells have high growth activity and are easily maintained in typical laboratory conditions. We have used this cell line in several cytotoxicity experiments $(16,18,19)$. In the present experiment, we also used another cell line of human origin, the MRC5 cell line, in order to evaluate the differential sensitivity of the two lines. Indeed, the RPC-C2A cells were more sensitive than the MRC5 cells in all settings and percentage of cell survival was overall lower in the RPCC2A cells.

The two brands of MTA were significantly less cytotoxic than SuperEBA and Vitrebond. These results are in agreement with other studies supporting the biocompatibility of MTA $(16,20-22)$. No statistically significant differences were observed in the degree of the cytotoxic effect displayed by MTA-Angelus and ProRoot MTA. The two commercial brands of MTA have similar chemical composition although ProRoot MTA is reported to present slightly higher percentages of bismuth oxide than MTA Angelus $(23,24)$. De Deus et al. (9) evaluated the cytotoxic effects of the two brands of MTA and Portland cement on human endothelial cells. No statistically significant difference was found among the materials tested, while the cytotoxic effect decreased gradually with time. In another study in which macrophages were exposed to MTA, the viability was greater than $97 \%$ at all examination periods and both ProRoot MTA and MTA Angelus exerted similar effect (8).

To the best of our knowledge, no published data exist about the cytotoxicity of MTA Angelus in dental pulp cells. The results of the present study showed that MTA Angelus exhibited very slight cytotoxic effect against pulp cells (RPC-C2A). Our results support the good biological behavior of MTA Angelus and they are well correlated to the findings of two relevant studies $(8,9)$ in which MTA Angelus is tested in endothelial cells and macrophages.

In this study, we tested the white formulations of MTA. White MTA has been introduced in clinical practice to overcome problems regarding coronal discoloration of teeth treated with gray MTA. Both white and gray types of MTA have similar cytotoxic effect (25) and when tested as pulpotomy agents, healing of the pulp and hard tissue bridge formation was observed (26).

SuperEBA cement consists of a powder containing zinc oxide $(60-75 \%)$, fused quartz or alumina (20-35\%) and hydrogenated resin (6\%) and a liquid containing 63\% ethoxybenzoic acid (EBA) and 37\% eugenol. The EBA encourages the formation of a crystalline structure that improves the strength of the material. The zinc oxideeugenol cements are generally inclined to cause inflammatory reactions in the tissues, mainly due to the presence of free eugenol. Several studies have shown the cytotoxic effect of SuperEBA that may be attributed to its eugenol content. Eugenol has been widely used as an antimicrobial and anti-inflammatory agent; however, previous in vitro and in vivo studies have demonstrated its toxic effects (27-32). It has been reported that eugenol inhibits cell migration, prostaglandin synthesis, cell respiration and mitochondrial activity (29-31). It also alters the cell membrane (29) and stimulates the neutrophils $(30,32)$

Vitrebond was the most potent material among those tested in the present study in all experimental settings. RMGICs have shown an increased cytotoxicity when tested in several studies. Souza et al. (33) evaluated the effect of three RMGICs applied on a culture of MDPC23 cells or implanted into subcutaneous tissue of rats. The materials induced a noticeable inflammatory response when they came in direct contact with connective tissue and Vitrebond showed the highest cytotoxic effect. The addition of leachable resin components, such as 2hydroxyethyl-methacrylate (HEMA), in RMGICs seems to be responsible for their cytotoxicity (34). HEMA is a very effective hydrophilic monomer that readily dissolves in water. It has been reported that Vitrebond releases a very high percentage of HEMA after immersion in distilled water, even when the material is light-cured (35). HEMA can suppress cell growth and proliferation (36), and can cause cell death by induction of apoptosis in cultured fibroblasts (37).

Under the present experimental conditions, ProRoot 
MTA and MTA Angelus exerted similar, favorable effects on the mitochodrial activity of fibroblasts. Although the in vitro results are not directly transferable to in vivo conditions, the application of both cements in clinical practice is encouraged.

\section{Acknowledgments}

The authors are grateful to Professor S. Kasugai for offering the RPC-C2A cell line.

\section{References}

1. Torabinejad M, Pitt Ford TR, McKennedy DJ, Abedi HR, Miller DA, Kariyawasam SP (1997) Histologic assessment of mineral trioxide aggregate as a rootend filling in monkeys. J Endod 23, 225-228

2. Economides N, Pantelidou O, Kokkas A, Tziafas D (2003) Short-term periradicular tissue response to mineral trioxide aggregate (MTA) as root-end filling material. Int Endod J 36, 44-48

3. Pitt Ford TR, Torabinejad M, McKendry DJ, Hong CU, Kariyawasam SP (1995) Use of mineral trioxide aggregate for repair of furcal perforations. Oral Surg Oral Med Oral Pathol Oral Radiol Endod 79, 756-763

4. Gaitonde P, Bishop K (2007) Apexification with mineral trioxide aggregate: an overview of the material and technique. Eur J Prosthodont Restor Dent 15, 41-45

5. O'Sullivan SM, Hartwell GR (2001) Obturation of a retained primary mandibular second molar using mineral trioxide aggregate: a case report. J Endod 27, 703-705

6. Tziafas D, Pantelidou O, Alvanou A, Belibasakis G, Papadimitriou S (2002) The dentinogenic effect of mineral trioxide aggregate (MTA) in short-term capping experiments. Int Endod J 35, 245-254

7. Min KS, Park HJ, Lee SK, Park SH, Hong CU, Kim HW, Lee HH, Kim EC (2008) Effect of mineral trioxide aggregate on dentin bridge formation and expression of dentin sialoprotein and heme oxygenase-1 in human dental pulp. J Endod 34, 666-670

8. Rezende TMB, Vargas DL, Cardoso FP, Sobrinho APR, Vieira LQ (2005) Effect of mineral trioxide aggregate on cytokine production by peritoneal macrophages. Int Endod J 38, 896-903

9. De Deus G, Ximenes R, Gurgel-Filho ED, Plotkowski MC, Coutinho-Filho T (2005) Cytotoxicity of MTA and Portland cement on human ECV 304 endothelial cells. Int Endod J 38, 604-609 10. Souza NJA, Justo GZ, Oliveira CR, Haun M,
Bincoletto C (2006) Cytotoxicity of materials used in perforation repair tested using the V79 fibroblast cell line and granulocyte-macrophage progenitor cells. Int Endod J 39, 40-47

11. Van Noort R (2007) Introduction to dental materials. 3rd ed, Mosby Elsevier, London, 127-143

12. Faraco IM Jr, Holland R (2001) Response of the pulp of dogs to capping with mineral trioxide aggregate or a calcium hydroxide cement. Dent Traumatol 17, 163-166

13. Pitt Ford TR, Torabinejad M, Abedi HR, Bakland LK, Kariyawasam SP (1996) Using mineral trioxide aggregate as a pulp-capping material. J Am Dent Assoc 127, 1491-1494

14. Paull KD, Shoemaker RH, Boyd MR, Parsons JL, Risbood PA, Barbera WA, Sharma MN, Baker DC, Hand E, Scudiero DA, Monks A, Alley MC, Grote M (1988) The synthesis of XTT: a new tetrazolium reagent that is bioreducible to a water-soluble formazan. J Heterocycl Chem 25, 911-914

15. Scudiero DA, Shoemaker RH, Paull KD, Monks A, Tierney S, Nofziger TH, Currens MJ, Seniff D, Boyd MR (1988) Evaluation of a soluble tetrazolium/formazan assay for cell growth and drug sensitivity in culture using human and other tumor cell lines. Cancer Res 48, 4827-4833

16. Koulaouzidou EA, Papazisis KT, Economides NA, Beltes P, Kortsaris AH (2005) Antiproliferative effect of mineral trioxide aggregate, zinc oxideeugenol cement, and glass-ionomer cement against three fibroblastic cell lines. J Endod 31, 44-46

17. Kasugai S, Adachi M, Ogura H (1988) Establishment and characterization of a clonal cell line (RPCC2A) from dental pulp of the rat incisor. Arch Oral Biol 33, 887-891

18. Koulaouzidou EA, Papazisis KT, Beltes P, Geromichalos GD, Kortsaris AH (1998) Cytotoxicity of three resin-based root canal sealers: an in vitro evaluation. Endod Dent Traumatol 14, 182-185

19. Koulaouzidou EA, Helvatjoglu-Antoniades M, Palaghias G, Karanika-Kouma A, Antoniades D (2008) Cytotoxicity evaluation of an antibacterial dentin adhesive system on established cell lines. J Biomed Mater Res B Appl Biomater 84, 271-276

20. Osorio RM, Hefti A, Vertucci FJ, Shawley AL (1998) Cytotoxicity of endodontic materials. J Endod 24, 91-96

21. Lin CP, Chen YJ, Lee YL, Wang JS, Chang MC, Lan WH, Chang HH, Chao WMW, Tai TF, Lee MY, Lin BR, Jeng JH (2004) Effects pf root-end filling materials and eugenol on mitochondrial 
dehydrogenase activity and cytotoxicity to human periodontal ligament fibroblasts. J Biomed Mater Res B Appl Biomater 71, 429-440

22. Karimjee CK, Koka S, Rallis DM, Gound TG (2006) Cellular toxicity of mineral trioxide aggregate mixed with an alternative delivery vehicle. Oral Surg Oral Med Oral Pathol Oral Radiol Endod 102, e115-120

23. Oliveira MG, Xavier CB, Demarco FF, Pinheiro ALB, Costa AT, Pozza DH (2007) Comparative chemical study of MTA and Portland cements. Braz Dent J 18, 3-7

24. Song JS, Mante FK, Romanow WJ, Kim S (2006) Chemical analysis of powder and set forms of Portland cement, gray ProRoot MTA, white ProRoot MTA, and gray MTA-Angelus. Oral Surg Oral Med Oral Pathol Oral Radiol Endod 102, 809-815

25. Holland R, Souza V, Nery MJ, Faraco Junior IM, Bernabé PF, Otoboni Filho JA, Dezan Júnior E (2002) Reaction of rat connective tissue to implanted dentin tubes filled with a white mineral trioxide aggregate. Braz Dent J 13, 23-26

26. Menezes R, Bramante CM, Letra A, Carvalho VG, Garcia RB (2004) Histologic evaluation of pulpotomies in dog using two types of mineral trioxide aggregate and regular and white Portland cements as wound dressings. Oral Surg Oral Med Oral Pathol Oral Radiol Endod 98, 376-379

27. Kasugai S, Hasegawa N, Ogura H (1991) Application of the MTT colorimetric assay to measure cytotoxic effects of phenolic compounds on established rat dental pulp cells. J Dent Res 70, $127-130$

28. Ho YC, Huang FM, Chang YC (2006) Mechanisms of cytotoxicity of eugenol in human osteoblastic cells in vitro. Int Endod J 39, 389-393
29. Fujisawa S, Kadoma Y, Kodama Y (1988) ${ }^{1} \mathrm{H}$ and ${ }^{13} \mathrm{C}$ NMR studies of the interaction of eugenol, phenol and triethleneglycol dimethacrylate with phospholipid liposomes as a model system for odontoblast membranes. J Dent Res 67, 1438-1441

30. Hume WR (1988) In vitro studies of the local pharmacodynamics, pharmacology and toxicology of eugenol and zinc oxide-eugenol. Int Endod J 21, $130-134$

31. Gerosa R, Borin M, Menegazzi G, Puttini M, Cavalleri G (1996) In vitro evaluation of the cytotoxicity of pure eugenol. J Endod 22, 532-534

32. McDonald JW, Heffner JE (1991) Eugenol causes oxidant-mediated edema in isolated perfused rabbit lungs. Am Rev Respir Dis 143, 803-809

33. Souza PPC, Aranha AMF, Hebling J, Giro, EMA, de Souza CA (2006) In vitro cytotoxicity and biocompatibility of contemporary resin-modified glass ionomer cements. Dent Mater 22, 838-844

34. Ratanasathien S, Wataha JC, Hanks CT, Dennison JB (1995) Cytotoxic interactive effects of dentin bonding components on mouse fibroblasts. J Dent Res 74, 1602-1606

35. Palmer G, Anstice HM, Pearson GJ (1999) The effect of curing regime on the release of hydroxyetyl methacrylate (HEMA) from resin-modified glassionomer cements. J Dent 27, 303-311

36. Hanks CT, Strawn SE, Wataha JC, Craig RG (1991) Cytotoxic effects of resin components on cultured mammalian fibroblasts. J Dent Res 70, 1450-1455

37. Spagnuolo G, Mauro C, Leonardi A, Santillo M, Paternó R, Schweikl H, Avvedimento EV, Rengo S. (2004) NF-kappaB protection against apoptosis induced by HEMA. J Dent Res 83, 837-842 